\title{
PHYSIOLOGICAL DOSE-RESPONSE OF COFFEE (Coffea arabica L.) PLANTS TO GLYPHOSATE DEPENDS ON GROWTH STAGE
}

\author{
Leonardo Bianco de Carvalho ${ }^{1 *}$, Pedro Luis da Costa Aguiar Alves², Silvano Bianco², \\ and Rafael De Prado ${ }^{3}$
}

\begin{abstract}
Glyphosate is the main herbicide used in coffee (Coffea arabica L.) plantations in Brazil. Problems with herbicide drift commonly occur in orchard fields due to non-adequate spraying conditions. A series of experiments was carried out aiming to evaluate physiological dose-response of $C$. arabica plants submitted to exposure to simulated glyphosate drift in two distinct plant growth stages. Glyphosate was applied at $0,180,360$, and $720 \mathrm{~g}$ acid equivalent (AE) ha ${ }^{-1}$ directly on coffee plants with 10 and $45 \mathrm{~d}$ after transplanting (DAT). Glyphosate doses in a range of 180-360 $\mathrm{g} \mathrm{AE} \mathrm{ha}^{-1}$ increased photosynthesis, transpiration and stomatal conductance in 10 DAT-plants up to $14 \mathrm{~d}$ after application (DAA) while, in 45 DAT-plants, an increase was observed only up to 2 DAA, but this pattern was not persistent afterwards so that no difference in gas exchange was observed at 60 DAA in both plants. Macronutrient content was not affected by glyphosate application in both plants. Plant DM accumulation was not affected by glyphosate application at 10 DAT-plants, but an increase in plant growth was observed when glyphosate was applied in a range of 360-720 g AE ha-1 in 45 DAT-plants. Coffea arabica cv. Catuaí Vermelho IAC-144 responded differentially to glyphosate drift depending on plant growth stage, regarding on photosynthesis, transpiration, stomatal conductance, and plant growth, in spite of macronutrient nutrition was not affected.
\end{abstract}

Key words: Coffea arabica, $N$-(phosphonomethyl)glycine, herbicide drift, photosynthesis, plant nutrition.

$\mathrm{C}$ offee (Coffea arabica L.) is one of the world's most popular beverages (Fujioka and Shibamoto, 2008) and the most important traded commodity in the world after oil (Naidu et al., 2008). Brazil is the main world producer where coffee production is of economic as well as social importance (Marana et al., 2008). Among coffee tree species planted in Brazil, C.arabica shows the highest economic importance, producing the consumers' most appreciated coffee drink (Nascimento et al., 2006).

An important issue for coffee production is weed management. Brazilian growers commonly use inter-row mechanical weeding associated to intra-row chemical control. So, herbicides can attain coffee plants as directly by accidental application as indirectly by spray drift, like reporting in other crops where similar weed management

${ }^{1}$ Universidade do Estado de Santa Catarina, Centro de Ciências Agroveterinárias (CAV/UDESC), Departamento de Agronomia, Avenida Luiz de Camões, 2.090, 88520-000, Lages, Brasil. *Corresponding author (lbcarvalho@cav.udesc.br).

${ }^{2}$ Universidade Estadual Paulista, Faculdade de Ciências Agrárias e Veterinárias (FCAV/UNESP), Departamento de Biologia Aplicada à Agropecuária, Via de acesso Prof. Paulo Donato Castellane, s/n, 14884-900, Jaboticabal, Brasil.

${ }^{3}$ Universidad de Córdoba, Escuela Técnica Superior de Ingeniería Agronómica y de Montes (ETSIAM/UCO), Departamento de Química Agrícola y Edafología, Carretera Madrid-Cádiz km 396, 14071, Córdoba, Spain.

Received: 6 October 2011.

Accepted: 25 May 2012. is used (Tuffi Santos et al., 2006; Gravena et al., 2009; Machado et al., 2010).

The main herbicide used in Brazilian coffee plantations is glyphosate ( $N$-(phosphonomethyl)-glycine). Effects of glyphosate on sensible plants are well understood, but, depending on herbicide dose, not only deleterious effects can be caused by exposing plants to the chemical. Many researchers have reported stimulatory effects of low glyphosate doses on growth of different plant species (Cedergreen et al., 2007; Velini et al., 2008; Cedergreen and Olesen, 2010), termed as hormesis.

Hormesis in plants has been in part attributed to a stimulation in gas exchange (Cedergreen and Olesen, 2010), a probable molecular mechanism (Cedergreen et al., 2007), a partial inhibition of 5-enolpyruvylshikimate3-phosphate synthase (EPSPS) and a more partitioning of C into sucrose (Velini et al., 2008). However, the mechanism of the stimulatory effect is not well understood, so that more research is needed to study probable effects of low doses of glyphosate in plants.

Previous experiments show that $C$. arabica plants show some tolerance to herbicide glyphosate (data not showed). So, we suppose that coffee plants could show hormetic response after being exposed to low doses of glyphosate depending on plant growth stages. Thus, the objective of this research was to evaluate if there is a different physiological dose-response of $C$. arabica plants submitted to exposure to simulated glyphosate drift in two distinct plant growth stages. 


\section{MATERIALS AND METHODS}

Plant material and growing conditions. Greenhouse experiments were carried out in Jaboticabal, Sao Paulo, from October 2009 to February 2010. Five-leaf seedlings of $C$. arabica cv. Catuaí Vermelho IAC-144 were transplanted to 7-L pots filled with substrate containing a mixture of manure and Red Latosol clay textured $(1: 3, \mathrm{v} / \mathrm{v})$ with $\mathrm{pH}\left(\mathrm{CaCl}_{2}\right)=5.1, \mathrm{OM}=20.0 \mathrm{~g} \mathrm{dm}^{-3} ; \mathrm{P}$ $($ resin $)=26.0 \mathrm{mg} \mathrm{dm}^{-3}, \mathrm{~K}=1.9, \mathrm{Ca}=23.0, \mathrm{Mg}=14.0$, $\mathrm{H}+\mathrm{Al}=25.0$, sum of bases $(\mathrm{SB})=38.9$, and cation exchange capacity $(\mathrm{CEC})=63.9 \mathrm{mmol}_{\mathrm{c}} \mathrm{dm}^{-3}$, and base saturation $(\mathrm{BS})=61 \%$. Substrate was fertilized with $3 \mathrm{~g}$ pot $^{-1}$ of NPK (4-14-8) fertilizer just after transplanting. Water was satisfactorily supplied every day. Fungicides (pyraclostrobin, epoxiconazole, and copper oxychloride) and insecticide (thiamethoxam) were fortnightly applied.

Herbicide and application conditions. A formulation of glyphosate with $48 \%(\mathrm{~m} / \mathrm{v})$ of active ingredient [isopropylamine salt of $N$-(phosphonomethyl)-glycine] and $36 \%$ of acid equivalent (AE) of $N$-(phosphonomethyl)glycine was used. Herbicide was applied using a $\mathrm{CO}_{2}-$ pressurized sprayer with flat plan nozzles (TeeJet, 80.02, Wheaton, Illinois, USA), pressure of $1.90 \mathrm{kgf} \mathrm{cm}^{-2}$, and water volume of application of $200 \mathrm{~L} \mathrm{ha}^{-1}$.

Treatments and experimental design. Treatments consisted of application of glyphosate at three subdoses $\left(180,360\right.$, and $\left.720 \mathrm{~g} \mathrm{AE} \mathrm{ha}^{-1}\right)$ directly on coffee plants at 10 and $45 \mathrm{~d}$ after transplanting (DAT), simulating different drift conditions. A non-treated control was also maintained. Experiments were set up in a factorial scheme with two main treatments (time of glyphosate application) and four secondary treatments (glyphosate doses). A completely randomized design was used with six replicates. Each experiment was repeated twice.

Evaluation time and measured characteristics. All experiments were evaluated at 2, 14, and $60 \mathrm{~d}$ after herbicide application (DAA) for gas exchange evaluation and only at 60 DAA for nutrition and growth evaluations. Gas exchange was evaluated based on photosynthesis, transpiration and stomatal conductance, using an infra red gas analyzer (LI6400, LI-COR, Lincoln, Nebraska, USA) with photosynthetically active radiation at $522 \mu \mathrm{mol}$ $\mathrm{m}^{-2} \mathrm{~s}^{-1}$ and leaf temperature at $25{ }^{\circ} \mathrm{C}$. Evaluations were performed in the second new pair of totally expanded leaves between 08:00 to 10:00 h of sunny days. Dry mass accumulation was determined after shoot was dried for 96 $\mathrm{h}$ in a forced air convection oven at $70{ }^{\circ} \mathrm{C}$. Macronutrient content in coffee shoot was determined according to methodologies described by Sarruge and Haag (1974) for $\mathrm{N}$ and P, by Jorgensen (1977) for K, Ca, and Mg, and by Vitti (1989) for S.
Statistical analysis. There was no interaction between treatments and experimental repetitions detected by previously ANOVA test (data not showed), so all data were pooled across experimental replicates for further analysis and presentation. All data were submitted to Tukey HSD post-hoc test at 5\% of probability, using Statistica software (StatSoft, Version 6.0, Tulsa, Oklahoma, USA).

\section{RESULTS AND DISCUSSION}

Gas exchange. Different responses were obtained when comparing plants whose exposure to glyphosate occurred at 10 and 45 DAT. Ten DAT-plants increased photosynthesis, transpiration and stomatal conductance when exposed to glyphosate at 180 and $360 \mathrm{~g} \mathrm{AE} \mathrm{ha}^{-1} \mathrm{up}$ to 14 DAA, but there was no difference in dose-response at 60 DAA (Table 1). On the other hand, 45 DAT-plants increased photosynthesis, transpiration and stomatal conductance when exposed to glyphosate at 180,360, and $720 \mathrm{~g} \mathrm{AE} \mathrm{ha}^{-1}$ up to $2 \mathrm{DAA}$, but there was no difference in dose-response at 14 and $60 \mathrm{DAA}$. These results indicate that gas exchange increases when young coffee plants are exposed to glyphosate drift but the effects are not persistent. Moreover, increased effects are dependent on plant growth stage.

Different results on gas exchange in plants exposed to glyphosate were obtained. Some authors found only deleterious effects in barley (Olesen and Cedergreen, 2010) and eucalyptus (Machado et al., 2010), while other ones also observed stimulation effects at low herbicide doses in barley (Cedergreen and Olesen, 2010), eucalyptus (Pereira et al., 2010) and sugar cane (Silva et al., 2009). Working with the same plant species, Olesen and Cedergreen (2010) and Cedergreen and Olesen (2010) verified different dose-response of barley to exposure to glyphosate, so that parthenin hormesis in plants can be dependent on growth conditions (Belz and Cedergreen, 2010).

Mechanisms of stimulation of gas exchange in plants are not well understood. An increase in $\mathrm{C}$ fixation rates can either be caused by increasing in light harvesting, which would increase growth under irradiance limiting growth conditions, or by increased efficiency of $\mathrm{C}$ fixation (Cedergreen and Olesen, 2010). The efficiency of $\mathrm{C}$ fixation rates could increase either through an increase in stomatal and mesophyl conductance (Purrington and Bergelson, 1999). Stomatal conductance is primarily regulated by phytohormones like abscisic acid, phaeseic acid, cytokinins, and gibberellins (Larcher, 2003), while short term mesophyl conductance is proposed to be regulated by aqua porins and carbonic anhydrase, facilitating the transport of $\mathrm{CO}_{2}$ over the cell wall (Flexas et al., 2008). An increase in the activity of the primary carboxylation enzyme ribulose-biphosphate carboxylase/ oxygenase (rubisco), increased turnover rates of the 
Table 1. Gas exchange in coffee plants under exposure to glyphosate at two different growth stages.

\begin{tabular}{|c|c|c|c|c|c|}
\hline Growth stage $^{1}$ & $\begin{array}{c}\text { Evaluation } \\
\text { time }^{2}\end{array}$ & Dose & Photosynthesis $^{3}$ & Transpiration $^{3}$ & Stomatal conductance ${ }^{3}$ \\
\hline \multirow{13}{*}{10 DAT } & \multirow{5}{*}{$2 \mathrm{DAA}$} & $\mathrm{g} \mathrm{AE} \mathrm{ha}^{-1}$ & $\mu \mathrm{mol} \mathrm{CO} 2 \mathrm{~m}^{-2} \mathrm{~s}^{-1}$ & $\mathrm{mmo}^{1} \mathrm{H}_{2} \mathrm{O} \mathrm{m^{-2 }} \mathrm{s}^{-1}$ & $\mathrm{~mol} \mathrm{H}_{2} \mathrm{O} \mathrm{m}^{-2} \mathrm{~s}^{-1}$ \\
\hline & & 0 & $4.89(0.25) \mathrm{D}$ & $1.35(0.01) \mathrm{EF}$ & $0.215(0.009)$ DEFG \\
\hline & & 180 & $6.66(0.20) \mathrm{BC}$ & $1.54(0.05) \mathrm{ABC}$ & $0.305(0.010) \mathrm{B}$ \\
\hline & & 360 & $6.13(0.36) \mathrm{BC}$ & $1.45(0.01) \mathrm{CDE}$ & $0.298(0.006) \mathrm{B}$ \\
\hline & & 720 & $4.76(0.09) \mathrm{D}$ & $1.33(0.01) \mathrm{FG}$ & $0.230(0.009) \mathrm{CDE}$ \\
\hline & \multirow{4}{*}{14 DAA } & 0 & $4.66(0.28) \mathrm{D}$ & $1.29(0.01) \mathrm{FG}$ & $0.194(0.005) \mathrm{G}$ \\
\hline & & 180 & $6.35(0.42) \mathrm{BC}$ & $1.48(0.01) \mathrm{CD}$ & $0.243(0.006) \mathrm{BCDE}$ \\
\hline & & 360 & $6.27(0.26) \mathrm{BC}$ & $1.47(0.03) \mathrm{BCD}$ & $0.236(0.004) \mathrm{CDE}$ \\
\hline & & 720 & $4.44(0.09) \mathrm{D}$ & $1.24(0.01) \mathrm{G}$ & $0.221(0.006) \mathrm{FG}$ \\
\hline & \multirow{4}{*}{$60 \mathrm{DAA}$} & 0 & $5.58(0.33) \mathrm{CD}$ & $1.22(0.02) \mathrm{G}$ & $0.209(0.009) \mathrm{FG}$ \\
\hline & & 180 & $5.71(0.39) \mathrm{BCD}$ & $1.26(0.02) \mathrm{FG}$ & $0.216(0.011) \mathrm{FG}$ \\
\hline & & 360 & $6.19(0.19) \mathrm{BC}$ & $1.33(0.03) \mathrm{FG}$ & $0.224(0.008) \mathrm{EFG}$ \\
\hline & & 720 & $5.77(0.28) \mathrm{BCD}$ & $1.24(0.04) \mathrm{G}$ & $0.219(0.007) \mathrm{FG}$ \\
\hline \multirow{12}{*}{45 DAT } & \multirow{4}{*}{$2 \mathrm{DAA}$} & 0 & $5.54(0.17) \mathrm{CD}$ & $1.45(0.01) \mathrm{CDE}$ & $0.255(0.006) \mathrm{CD}$ \\
\hline & & 180 & $7.23(0.07) \mathrm{AB}$ & $1.61(0.01) \mathrm{A}$ & $0.355(0.008) \mathrm{A}$ \\
\hline & & 360 & $7.86(0.10) \mathrm{A}$ & $1.61(0.01) \mathrm{A}$ & $0.353(0.012) \mathrm{A}$ \\
\hline & & 720 & $6.88(0.26) \mathrm{AB}$ & $1.57(0.02) \mathrm{AB}$ & $0.325(0.008) \mathrm{AB}$ \\
\hline & \multirow{4}{*}{14 DAA } & 0 & $6.23(0.13) \mathrm{BC}$ & $1.47(0.02) \mathrm{BCD}$ & $0.218(0.005) \mathrm{CDEF}$ \\
\hline & & 180 & $6.89(0.15) \mathrm{AB}$ & $1.53(0.02) \mathrm{ABC}$ & $0.235(0.009) \mathrm{CDE}$ \\
\hline & & 360 & $7.18(0.31) \mathrm{AB}$ & $1.54(0.01) \mathrm{ABC}$ & $0.257(0.011) \mathrm{C}$ \\
\hline & & 720 & $6.80(0.12) \mathrm{AB}$ & $1.48(0.01) \mathrm{BCD}$ & $0.236(0.009) \mathrm{CDE}$ \\
\hline & \multirow{4}{*}{$60 \mathrm{DAA}$} & 0 & $6.83(0.21) \mathrm{AB}$ & $1.54(0.05) \mathrm{ABC}$ & $0.232(0.009) \mathrm{CDEF}$ \\
\hline & & 180 & $6.24(0.13) \mathrm{BC}$ & $1.44(0.02) \mathrm{ABCD}$ & $0.217(0.009) \mathrm{CDEFG}$ \\
\hline & & 360 & $6.88(0.31) \mathrm{AB}$ & $1.61(0.04) \mathrm{A}$ & $0.258(0.021) \mathrm{CD}$ \\
\hline & & 720 & $6.41(0.42) \mathrm{ABC}$ & $1.50(0.02) \mathrm{ABC}$ & $0.229(0.014) \mathrm{CDEF}$ \\
\hline
\end{tabular}

${ }^{1}$ DAT: days after transplanting.

${ }^{2}$ DAA: days after herbicide application.

${ }^{3}$ Means followed by the same letter in columns are not different according to Tukey HSD post-hoc test at 5\% of probability.

rubisco substrate ribulose-biphosphate $(\mathrm{RuBP})$ or an increased rate of use of triose phosphate can also increase the efficiency of C fixation (Sharkey et al., 2007). One mechanism, by which carboxylating enzyme activity is increased, is by alleviation of the feedback inhibition of sugars on the carboxylating enzyme activity (Cedergreen and Olesen, 2010). These situations occur when export of sugars to sink tissues (or plant symbionts or pathogens) increase and result in increased light and $\mathrm{CO}_{2}$ saturated photosynthetic rates in source tissue (Pego et al., 2000; Berger et al., 2007; Ainsworth and Rogers, 2007).

It was proposed that net photosynthesis was increased, possibly by an increased translocation of photosynthates from the source leaves (Su et al., 1992). Increased sucrose concentrations have been demonstrated to activate phloem loading proteins (Vaughn et al., 2002). It has been suggested that a decreased level of precursors of lignin could make cells elongate for a longer time (Duke et al., 2006), thereby creating an increased sink for C, but there is as yet no evidence supporting this hypothesis. Also, an increased root growth could create a larger sink for carbohydrates. Experiments with hydrophonic cultures of barley actually showed a significant $10-30 \%$ increase in the root:shoot dry weight ratio of sprayed plants. This, however, was not the case for plants exposed to glyphosate through the media, which also showed hormesis, hence, the explanation does not seem to be general (Cedergreen, 2008).

Plant nutrition. Content of $\mathrm{N}, \mathrm{P}, \mathrm{K}, \mathrm{Ca}, \mathrm{Mg}$ and $\mathrm{S}$ in coffee plants was not affected by glyphosate drift in both 10 DAT-plants and 45 DAT-plants up to 60 DAA (Table
2). These results indicate that macronutrient content does not change when young coffee plants are exposed to glyphosate drift up to 45 DAT.

Reduction in nutrient content in coffee plants was observed, excepting for $\mathrm{Ca}$ that increased (França et al., 2010b). According to these authors, that increase occurs because of more root exudates production due to glyphosate action, also augmenting microbial soil activity, and permitting that calcium concentration in the soil solution was increased and more calcium can be uptake by plants, as discussed by França et al. (2010b). If this affirmative is right, we did not observed Ca content increase in both 10 and 45 DAT-plants due

Table 2. Content of macronutrients in shoot of coffee plants under exposure to glyphosate at two different growth stages.

\begin{tabular}{|c|c|c|c|c|}
\hline $\begin{array}{l}\text { Growth } \\
\text { stage }^{1}\end{array}$ & Dose & Nitrogen $^{2}$ & Phosphorus $^{2}$ & Potassium $^{2}$ \\
\hline & $\mathrm{g} \mathrm{AE} \mathrm{ha-1}$ & & $-\mathrm{g} \mathrm{kg}^{-1} \mathrm{DM}$ & \\
\hline \multirow[t]{4}{*}{10 DAT } & 0 & $19.3(0.5) \mathrm{A}$ & $1.88(0.02) \mathrm{A}$ & $17.0(0.6) \mathrm{A}$ \\
\hline & 180 & $19.0(0.4) \mathrm{A}$ & $1.89(0.06) \mathrm{A}$ & $16.7(0.1) \mathrm{A}$ \\
\hline & 360 & $19.5(0.2) \mathrm{A}$ & $1.87(0.03) \mathrm{A}$ & $16.6(0.3) \mathrm{A}$ \\
\hline & 720 & $19.8(0.6) \mathrm{A}$ & $1.86(0.02) \mathrm{A}$ & $17.5(0.4) \mathrm{A}$ \\
\hline \multirow[t]{5}{*}{45 DAT } & 0 & $19.0(0.5) \mathrm{A}$ & $1.88(0.02) \mathrm{A}$ & $17.3(0.6) \mathrm{A}$ \\
\hline & 180 & $19.1(0.6) \mathrm{A}$ & $1.88(0.06) \mathrm{A}$ & $16.7(0.1) \mathrm{A}$ \\
\hline & 360 & $20.2(0.3) \mathrm{A}$ & $1.91(0.03) \mathrm{A}$ & $16.6(0.3) \mathrm{A}$ \\
\hline & 720 & $20.0(0.7) \mathrm{A}$ & $1.86(0.02) \mathrm{A}$ & $17.5(0.3) \mathrm{A}$ \\
\hline & & Calcium $^{2}$ & Magnesium $^{2}$ & Sulfur $^{2}$ \\
\hline \multirow[t]{4}{*}{10 DAT } & 0 & $10.1(0.5) \mathrm{A}$ & $2.61(0.11) \mathrm{A}$ & $0.41(0.02) \mathrm{A}$ \\
\hline & 180 & $10.7(0.6) \mathrm{A}$ & $2.75(0.12) \mathrm{A}$ & $0.42(0.02) \mathrm{A}$ \\
\hline & 360 & $10.6(0.7) \mathrm{A}$ & $2.80(0.04) \mathrm{A}$ & $0.40(0.01) \mathrm{A}$ \\
\hline & 720 & $10.8(0.6) \mathrm{A}$ & $2.69(0.16) \mathrm{A}$ & $0.39(0.01) \mathrm{A}$ \\
\hline \multirow[t]{4}{*}{$45 \mathrm{DAT}$} & 0 & $10.2(0.6) \mathrm{A}$ & $2.78(0.04) \mathrm{A}$ & $0.44(0.01) \mathrm{A}$ \\
\hline & 180 & $10.7(0.6) \mathrm{A}$ & $2.79(0.12) \mathrm{A}$ & $0.37(0.02) \mathrm{A}$ \\
\hline & 360 & $9.7(0.4) \mathrm{A}$ & $2.83(0.03) \mathrm{A}$ & $0.43(0.01) \mathrm{A}$ \\
\hline & 720 & $11.6(1.5) \mathrm{A}$ & $2.76(0.14) \mathrm{A}$ & $0.40(0.02) \mathrm{A}$ \\
\hline
\end{tabular}

${ }^{1}$ DAT: days after transplanting.

${ }^{2}$ Means followed by the same letter in columns are not different according to Tukey HSD post-hoc test at $5 \%$ of probability. 
probably to low microbial activity in our substrate. However, many different results have been observed in respect to effects of glyphosate on plant nutrition in several crops (Ozturk et al., 2008; Cakmak et al., 2009; Su et al., 2009; Yamada et al., 2009), so that it is not possibly to establish any pattern of plant doseresponses for each nutrient.

Plant growth. Dry mass accumulation increased when coffee plants were exposed to glyphosate drift at 360 and $720 \mathrm{~g} \mathrm{AE} \mathrm{ha}^{-1}$ at 45 DAT (Table 3). On the other hand, DM accumulation at 10 DAT-plants was not influenced by exposure to glyphosate. These results indicate that glyphosate drift increases coffee plant growth when exposure occurs in more advanced growth stage of young coffee plants.

The physiological mechanisms behind this apparent counter intuitive change in growth are currently unknown. From a theoretical viewpoint it is unlikely that respiration rates decrease, as additions of xenobiotics usually induce detoxification processes which are energy demanding (Cole, 1994; Purrington and Bergelson, 1999), so that net photosynthesis should be increased by an increase in $\mathrm{C}$ fixation rates that can either be caused by an increase in light harvesting, which would increase growth under irradiance limiting growth conditions, or by increased efficiency of $\mathrm{C}$ fixation (Cedergreen and Olesen, 2010). However, in this case, hormetic effect does not be attributed to increase in net photosynthesis or general gas exchange, because 10 DAT-plants showed stimulatory effect in gas exchange up to 14 DAA, as well as 45 DAT-plants showed only up to 2 DAA, but this effect was not persistent in both plants. So, if gas exchange had influenced on plant growth, 10 DATplants also should show stimulation in plant growth. Hormetic effect does not be also attributed to changes in macronutrient content. Thus, we guess that hormesis with glyphosate in coffee young plants occurs due to a probable molecular mechanism, a partial inhibition of EPSPS or/and a more partitioning of $\mathrm{C}$ into sucrose, as discussed by Cedergreen et al. (2007) and Velini et al. (2008).

Different response between 10 and 45 DAT-plants can

Table 3. Dry mass accumulation in shoot of coffee plants under exposure to glyphosate at two different growth stages.

\begin{tabular}{lcc}
\hline Growth stage & Dose & Dry matter $^{2}$ \\
\hline \multirow{3}{*}{ 10 DAT } & g AE ha $^{-1}$ & g plant $^{-1}$ \\
& 0 & $19.15(0.62) \mathrm{C}$ \\
& 180 & $19.10(0.77) \mathrm{C}$ \\
& 360 & $19.09(0.50) \mathrm{C}$ \\
45 DAT & 720 & $18.51(0.26) \mathrm{C}$ \\
& 0 & $29.60(0.98) \mathrm{B}$ \\
& 360 & $32.38(1.12) \mathrm{AB}$ \\
& 720 & $35.71(0.80) \mathrm{A}$ \\
\end{tabular}

DAT: days after transplanting; AE: acid equivalent.

Means followed by the same letter are not different according to Tukey HSD post-hoc test at $5 \%$ of probability. have occurred due to higher glyphosate concentration attaining its site of action in 10 DAT-plants. 10 DAT-plants showed lesser number of leaves and stem ramifications than 45 DAT-plants at the moment of glyphosate application. In addition, youngest plants show thinner epicuticular wax layers (Michitte et al., 2007; Nandula et al., 2008) and less intense metabolism than older ones. In any case, being glyphosate a polar herbicide, more chemical can penetrate into plant tissue and attain its site of action, so that higher concentration of active ingredient should be present in 10 DAT-plants and, in this way, no stimulation or even deleterious effects will be occur more easily.

General considerations. A few studies on effects of glyphosate in coffee plants were found. Hormesis with glyphosate was not observed in coffee plant growth in a range of doses from 57.6 to $460.8 \mathrm{~g} \mathrm{AE} \mathrm{ha}^{-1}$, but a significant reduction in plant height, leaf area, stem dry mass, leaf dry mass, and root density was verified (França et al., 2010a) as well as reductions in leaf nutrient content were observed (França et al., 2010b). Field observations indicated that effects of glyphosate can persist until harvesting, also reducing coffee grain yield (Nelson, 2008). Actually, different dose-responses are expected since parthenin hormesis in plants depends on growth conditions (Belz and Cedergreen, 2010) and plant growth stage (Velini et al., 2008), so that sub-lethal glyphosate doses have not to be indicated for using in agricultural conditions.

Present work is fundamental to show that coffee plants cv. Catuaí Vermelho IAC-144 are tolerant to sub-doses of glyphosate. So, all the deleterious effects observed in the field that are attributed to the glyphosate drift can be misunderstood. Further research is needed to evaluate the effects of glyphosate low doses on plants and to understand the mechanisms involved. Such work is fundamental to improving present knowledge of glyphosate dynamics in production systems and to having precise information about the effects of glyphosate on non-target plants (Velini et al., 2008).

\section{CONCLUSIONS}

Taken together, our results allow us to conclude that coffee plants ( . arabica cv. Catuaí Vermelho IAC-144) respond differentially to glyphosate drift depending on plant growth stage, regarding on photosynthesis, transpiration, stomatal conductance and plant growth, in spite of macronutrient nutrition was not affected.

\section{ACKNOWLEDGEMENTS}

We would like to thank Conselho Nacional de Desenvolvimento Científico e Tecnológico (CNPq) for doctorate scholarship provided to the first author. 
Respuesta fisiológica de plantas de café (Coffea arabica L.) a glifosato depende de la etapa de crecimiento. Glifosato es el principal herbicida utilizado en las plantaciones de café (Coffea arabica L.) en Brasil. Problemas con la deriva de herbicidas comúnmente ocurren en los campos de cultivo debido a condiciones no adecuadas de pulverización. Una serie de experimentos se llevó a cabo con el objetivo de evaluar la relación dosis-respuesta fisiológica de plantas de $C$. arabica expuestas a situaciones simuladas de exposición a deriva de glifosato en dos etapas distintas de crecimiento de las plantas. El glifosato se aplicó en dosis de 0, 180, 360, y $720 \mathrm{~g}$ equivalentes ácido (AE) $\mathrm{ha}^{-1}$ directamente en las plantas de café a los 10 y 45 d después del trasplante (DDT). Dosis de glifosato en un rango de 180-360 g AE ha-1, aumentaron la fotosíntesis, la transpiración y la conductancia estomática en plantas con 10 DDT hasta 14 d después de la aplicación de glifosato (DAA), mientras que en plantas con 45 DDT se observó un aumento sólo hasta 2 DAA, pero no fue persistente, de modo que no se observó diferencia en el intercambio de gases a los 60 DDA en ambas plantas. El contenido de macronutrientes de las plantas a los 10 DDA no fue afectado por las épocas de aplicación de glifosato. La acumulación de MS a los 10 DDA no fue afectada por la aplicación de glifosato, pero a los 45 DDA se observó un aumento del crecimiento de las plantas con glifosato en dosis de 360-720 $\mathrm{g} \mathrm{AE} \mathrm{ha}^{-1}$ Coffea arabica cv. Catuaí Vermelho IAC-144 respondió de forma diferente a la deriva de glifosato en función de la etapa del crecimiento de las plantas, con respecto a fotosíntesis, transpiración, conductancia estomática, y crecimiento de las plantas, a pesar que la nutrición en macronutrientes no se vio afectada.

Palabras clave: Coffea arabica, $N$-(fosfonometil) glicina, deriva de herbicida, fotosíntesis, nutrición de plantas.

\section{LITERATURE CITED}

Ainsworth,E.A., and A. Rogers. 2007. The response of photosynthesis and stomatal conductance to rising $\left[\mathrm{CO}_{2}\right]$ : mechanisms and environmental interactions. Plant Cell and Environment 30:258270.

Belz, R.G., and N. Cedergreen. 2010. Parthenin hormesis in plants depends on growth conditions. Environmental and Experimental Botany 69:293-301.

Berger, S., A.K. Sinha, and T. Roitsch. 2007. Plant physiology meets phytopathology: plant primary metabolism and plant-pathogen interactions. Journal of Experimental Botany 58:4019-4026.

Cakmak, I., A. Yazici, Y. Tutus, and L. Ozturk. 2009. Glyphosate reduced seed and leaf concentrations of calcium, manganese, magnesium, and iron in non-glyphosate resistant soybean. European Journal of Agronomy 31:114-119.

Cedergreen, N. 2008. Is the growth stimulation by low doses of glyphosate sustained over time? Environmental Pollution 156:1099-1104.

Cedergreen, N., and C.F. Olesen. 2010. Can glyphosate stimulate photosynthesis? Pesticide Biochemistry and Physiology 96:140148 .
Cedergreen, N., J.C. Streibig, P. Kudsk, S.K. Mathiassen, and S.O. Duke. 2007. The occurrence of hormesis in plants and algae. Dose Response 5:150-162.

Cole, D.J. 1994. Detoxification and activation of agrochemicals in plants. Pesticide Science 42:209-222.

Duke, S.O., N. Cedergreen, E.D. Velini, and R.G. Belz. 2006 Hormesis: is it an important factor in herbicide use and allelopathy? Outlooks on Pest Management 17:29-33.

Flexas, J., M. Ribas-Carbó, A. Diaz-Espejo, J. Galmes, and H. Medrano. 2008. Mesophyll conductance to $\mathrm{CO}_{2}$ : current knowledge and future prospects. Plant Cell and Environment 31:602-621.

França, A.C., M.A.M. Freitas, L. D'Antonino, C.M.T. Fialho, A.A Silva, M.R. Reis, and C.P. Ronchi. 2010b. Nutrient content in arabica coffee cultivars submitted to glyphosate drift. Planta Daninha 28:877-885.

França, A.C., M.A.M. Freitas, C.M.T. Fialho, A.A. Silva, M.R. Reis, L. Galon, and R. Victoria Filho. 2010a. Growth of arabica coffee cultivars submitted to glyphosate doses. Planta Daninha 28:599607.

Fujioka, K., and T. Shibamoto. 2008. Chlorogenic acid and caffeine contents in various commercial brewed coffees. Food Chemistry 106:217-221.

Gravena, R., R. Victoria Filho, P.L.C.A. Alves, P. Mazzafera, and A.R. Gravena. 2009. Low glyphosate rates do not affect Citrus limonia (L.) Osbeck seedlings. Pest Management Science 65:420425 .

Jorgensen, S.S. 1977. Metodologia utilizada para análises químicas de rotina: guia analítico. 24 p. Centro de Energia Nuclear na Agricultura (CENA), Piracicaba, Brasil.

Larcher, W. 2003. Physiological plant ecology. 513 p. Springer, Berlin, Germany.

Machado, A.F.L., L.R. Ferreira, L.D.T. Santos, F.A. Ferreira, R.G Viana, M.S. Machado, and F.C.L. Freitas. 2010. Photosynthetic efficiency and water use in eucalyptus plants sprayed with glyphosate. Planta Daninha 28:319-327.

Marana, J.P., E. Miglioranza, E.P. Fonseca, and R.H. Kainuma. 2008 Seedling quality in coffee grown in containers. Ciência Rural 38:39-45

Michitte, P., R. De Prado, N. Espinoza, J.P. Ruiz-Santaella, and C. Gauvrit. 2007. Mechanisms of resistance to glyphosate in a ryegrass (Lolium multiflorum) biotype from Chile. Weed Science 55:435-440.

Naidu, M.M., G. Sulochanamma, S.R. Sampathu, and P. Srinivas 2008. Studies on extraction and antioxidant potential of green coffee. Food Chemistry 107:377-384.

Nandula, V.K., K.N. Reddy, D.H. Poston, A.M. Rimando, and S.O Duke. 2008. Glyphosate tolerance mechanism in Italian ryegrass (Lolium multiflorum) from Mississippi. Weed Science 56:344349 .

Nascimento, E.A., L.E.M. Oliveira, E.M. Castro, N. Delú Filho, A.C. Mesquita, and C.V. Vieira. 2006. Alterações morfofisiológicas em folhas de cafeeiro (Coffea arabica $\mathrm{L}$.) consorciado com seringueira (Hevea brasiliensis Muell. Arg.) Ciência Rural 36:852-857.

Nelson, S. 2008. Glyphosate herbicide injury to coffee plants. Available at http://www.ctahr.hawaii.edu/oc/freepubs/pdf/PD-56. pdf (accessed 5 September 2011).

Olesen, C.F., and N. Cedergreen. 2010. Glyphosate uncouples gas exchange and chlorophyll fluorescence. Pest Management Science 66:536-542.

Ozturk, L., A. Yazici, S. Eker, O. Gokmen, V. Römheld, and I Cakmak. 2008. Glyphosate inhibition of ferric reductase activity in iron deficient sunflower roots. New Phytologist 177:899-906.

Pego, J.V., A.J. Kortstee, G. Huijser, and S.G.M. Smeekens. 2000. Photosynthesis, sugars and the regulation of gene expression. Journal of Experimental Botany 51:407-416.

Pereira, M.R.R., A.C.P. Rodrigues, N.V. Costa, D. Martins, A.E Klar, and M.R. Silva. 2010. Glyphosate drift effect on some physiological features of eucalyptus plants. Interciencia 35:279283. 
Purrington, C.B., and J. Bergelson. 1999. Exploring the physiological basis of costs of herbicide resistance in Arabidopsis thaliana. American Naturalist 154:S82-S91.

Sarruge, J.R., and H.P. Haag. 1974. Análises químicas em plantas. 56 p. Escola Superior de Agricultura Luiz de Queiroz (ESALQ), Piracicaba, Brasil.

Sharkey, T.D., C.J. Bernacchi, G.D. Farquhar, and E.L. Singsaas. 2007. Fitting photosynthetic carbon dioxide response curves for C-3 leaves. Plant Cell and Environment 30:1035-1040.

Silva, A.F., G. Concenço, I. Aspiazú, E.A. Ferreira, L. Galon, A.T.C.P. Coelho, A.A. Silva, and F.A. Ferreira. 2009. Interference of different weed densities in soybean growth. Planta Daninha 27:75-84.

Su, L.Y., A.D. Cruz, P.H. Moore, and A. Maretzki. 1992. The relationship of glyphosate treatment to sugar metabolism in sugarcane: new physiological insights. Journal of Plant Physiology 140:168-173.

Su, Y.S., L. Ozturk, I. Cakmak, and H. Budak. 2009. Turfgrass species response exposed to increasing rates of glyphosate. European Journal of Agronomy 31:120-125.
Tuffi Santos, L.D., F.A. Ferreira, L.R. Ferreira, W.M. Duarte, R.A.S. Tiburcio, and M.V.V. Santos. 2006. Intoxication of eucalypt species under glyphosate drift. Planta Daninha 24:359-364.

Vaughn, M.W., G.N. Harrington, and D.R. Bush. 2002. Sucrosemediated transcriptional regulation of sucrose symporter activity in the phloem. Proceedings of the National Academy of Science of the United States of America 99:10876-10880.

Velini, E.D., E. Alves M.C. Godoy, D.K. Meschede, R.T. Souza, and S.O. Duke. 2008. Glyphosate applied at low doses can stimulate plant growth. Pest Management Science 64:489-496.

Vitti, G.C. 1989. Avaliação e interpretação do enxofre no solo e na planta. 37 p. Fundação de Apoio a Pesquisa, Ensino e Extensão (FUNEP), Jaboticabal, Brasil.

Yamada, T., R.J. Kremer, P.R. Camargo e Castro, and B.W. Wood. 2009. Glyphosate interactions with physiology, nutrition, and diseases of plants: threat to agricultural sustainability? European Journal of Agronomy 31:111-113. 